\title{
Factors that Condition Seasonality in Farmer's Employment in Farm, in Income, Sales and Price at Farm Level - for the Apple and Tomato Products
}

\author{
PhD. Eriona Deda \\ Faculty of Economics and Agribusiness, \\ Agricultural University of Tirana
}

Doi: $10.2478 / \mathrm{mjss}-2018-0093$

\begin{abstract}
This paper is focused on several factors that cause seasonality in farmers work occupation, farm income, sales, and price expressed on the farm level for apples product. In this study we have taken several factors, and we have analyzed seasonality caused by the seasonal factors that we have taken in study, on economic phenomena expressed at the farm level, and whether apple is product with main activity on the farm. Seasonality has been expressed by method of econometric modeling and variance coefficient. Our study is based on the collection of primary data through surveys and questionnaires for 300 farmers that are engaged on apples and tomatoes activity in three respective areas, Korça, Prizren, Lushnja and we have evaluated the seasonality conditioned by seasonal factors in income, farmers employment over the year, sales and price at farm level, bearing in mind that for the Korça and Prizren areas the main activity on the farm is apples. And for Lushnja area the main activity is tomatoes. In this study we have taken into account the comparison of influence of these seasonal factors on basis of apple and tomato products, analyzing only for case when apple is the main activity on the farm.
\end{abstract}

Keywords: seasonality, seasonal factors, main activity, farm level

\section{Introduction}

Through this paper we will evaluate the pattern of dependence by some factors that cause seasonality in farmer's income, employment, sales and price at farm level, having apples product the main activity on the farm.

Using econometric modeling method and the variance coefficient, we will determine if the model is statistically significant and what are seasonal factors that condition seasonality of income, price, sales, and farmer employment in farm over the year.

The study is focused on assessing the seasonality based on comparison between products at the farm level, when apple is the main activity on farm and is not focused specifically assessing seasonlity by the areas.

\section{Research Methods}

Methods that we used in this paper are econometric modeling method, and coefficient of variance by which we have determined the seasonality. ${ }^{1}$ coefficient of variation that is a relative indicator that expresses the magnitude of the ratio between the standard deviation and the arithmetic mean of the mass phenomenon.

For four baseline indicators of analysis, we take as a dependent variables the seasonality, and through respective variance coefficient try to identify which ones may be some of main causes or sources of seasonality according to the indicators. The data are primary, and quartely, for a year. The data are collected from farmers interview in relevant areas through surveys and questionnaires

\footnotetext{
${ }^{1}$ Osmani, M. (2004). Coefficient of variation (pp.99-101). Tirana, Albania: GEER, 2004
} 


\section{Purpose of this Paper}

The purpose of this study is to evaluate pattern of dependence on some factors that cause seasonality in farmer's income, farmer's labor, sales and price at farm level where apple product is the main activity on farm

\subsection{The research Questions}

Which are the seasonal factors that condition the seasonality in economic phenomena taken in the study, such as farmer`s income, farmer` labour, sales and price?

\section{The Data and Choice}

We have primary data and have collected them through farmers' surveys and questionnaires for the Korça , Lushnja and Prizren areas, only for the case where farmers have as the main activity apple's product. In the study, we have taken on some important seasonal factors that condition seasonality in farmer's income, sales, price, and farmer's employment over a year.

Some of these seasonal factors that cause seasonality in the economic phenomena taken in study ,are expressed in the questionnaire consisting of 4 options, from which we have collected the data for farmers, and have determined which seasonal factors condition more seasonality in the economic phenomena taken in study, where the main activity on farm is apple.

Regarding to the technique sampling choice, is accidental technique.

\begin{tabular}{|c|l|l|l|l|l|}
\hline $\begin{array}{c}\text { Question } \\
\text { Codes }\end{array}$ & Questions & \multicolumn{3}{|c|}{ Answer } \\
\hline S1 & $\begin{array}{l}\text { The temperatures changes by seasons has effected } \\
\text { that production to be differentiated according to } \\
\text { seasons }\end{array}$ & $\begin{array}{c}\text { I'm } \\
\text { disagree }\end{array}$ & $\begin{array}{c}\text { I'm little bit } \\
\text { agreed }\end{array}$ & $\begin{array}{l}\text { I'm agreed } \\
\text { acm very } \\
\text { agreed }\end{array}$ \\
\hline S2 & $\begin{array}{l}\text { Lack of co-operation has effected on the price by } \\
\text { seasons }\end{array}$ & & & & \\
\hline S3 & $\begin{array}{l}\text { Increasing temperatures in summer has had positive } \\
\text { effect on winter production }\end{array}$ & & & & \\
\hline S4 & $\begin{array}{l}\text { Increasing temperatures in winter has effected in the } \\
\text { rise price in winter }\end{array}$ & & & & \\
\hline S5 & $\begin{array}{l}\text { The flood has had a negative effect on production by } \\
\text { season }\end{array}$ & & & & \\
\hline S6 & $\begin{array}{l}\text { Current irrigation infrastructure has had a positive role } \\
\text { in production }\end{array}$ & & & & \\
\hline S7 & $\begin{array}{l}\text { Lack of investment didn't affected the differentiation of } \\
\text { production by seasons }\end{array}$ & & & & \\
\hline S8 & $\begin{array}{l}\text { Lack of investment didn't affected the price } \\
\text { differentiation by seasons }\end{array}$ & & & & \\
\hline S9 & $\begin{array}{l}\text { Lack of storage-cooling capacities hasn't affected the } \\
\text { price differentiation by seasons }\end{array}$ & & & & \\
\hline S10 & Agricultural inputs are of a high price & & & \\
\hline S11 & $\begin{array}{l}\text { Inputs such as: (fertilizers, pesticides) are lacking or } \\
\text { are of poor quality }\end{array}$ & & & & \\
\hline S12 & $\begin{array}{l}\text { The farmers doesn't have knowledge about new } \\
\text { technologies and techniques }\end{array}$ & & & & \\
\hline S13 & The farmer has difficulties in selling & & & \\
\hline S14 & The quality of farm produce, apple (tomatoes), is poor & & & & \\
\hline S15 & The main selling market is far away & & & \\
\hline S16 & Road infrastructure is poor & & & \\
\hline S17 & Competition from imports is unfair & & & \\
\hline S18 & The farmers doesn't sell the product under a contract & & & \\
\hline
\end{tabular}




\section{Analysis Result}

5.1 The estimation of seasonality dependence in income from seasonal factors by econometric modeling.

\subsubsection{The econometric model for the seasonality dependence of income}

Dependent Variable: Income CV

Method: ${ }^{2}$ Least Squares

Sample: 1300

Included observations: 300

\begin{tabular}{lllll}
\hline \hline Variable & Coefficient & Std. Error & t-Statistic & Prob. \\
\hline \hline C & 102.6357 & 6.083326 & 16.87164 & 0.0000 \\
Seasons factor 18 & 4.180796 & 2.004496 & 2.085710 & 0.0379 \\
Seasons factor 3 & -6.742871 & 1.618824 & -4.165291 & 0.0000 \\
Seasons factor 6 & -8.194202 & 1.426845 & -5.742883 & 0.0000 \\
Seasons factor 14 & 3.614635 & 1.422738 & 2.540619 & 0.0116 \\
Seasons factor 13 & 1.981094 & 1.233018 & 1.606703 & 0.1092 \\
Apples, is the main activity & 58.22337 & 2.011205 & 28.94949 & 0.0000 \\
\hline \hline R-squared & 0.849394 & Mean dependent var & 135.6238 \\
Adjusted R-squared & 0.846310 & S.D. dependent var & 39.62418 \\
S.E. of regression & 15.53398 & Akaike info criterion & 8.346994 \\
Sum squared resid & 70702.23 & Schwarz criterion & 8.433415 \\
Log likelihood & -1245.049 & F-statistic & 275.4130 \\
Durbin-Watson stat & 1.455758 & Prob(F-statistic) & 0.000000 \\
\hline \hline
\end{tabular}

The coefficient of variance related to income $=102.6356568+4.180796304^{*}$ Seasons factor $18-6.742870925^{\star}$ Season factor $3-8.194201827^{\star}$ Season factor $6+3.614634846^{\star}$ Season factor $14+1.981093802^{*}$ Season factor $3+58.22337148^{*}$ Apples , the main activity

The model is statistically important for high security with determination coefficient about $85 \%$. From the assessment results that seasonality of income is influenced by seasonal factors S3, S6, S13, S14 and S18. The seasonality in income depends on increases in winter's production by rising temperatures, lack of sales contracts, poor irrigation infrastructure, poor quality of farm produce and the difficulties of sales. There are significant differences between products apples and tomatoes. When apples product is the main activity in farm, seasonality is lower $(58.2 \%)$. The farm size in this case results unsignificant

\subsection{The estimation of seasonality dependence in sales from seasonal factors by econometric modeling.}

\subsubsection{The econometric model for the seasonality dependence of sales}

Dependent Variable: Sales CV

Method: Least Squares

Sample: 1300

Included observations: 300

\begin{tabular}{lllll}
\hline \hline Variable & Coefficient & Std. Error & t-Statistic & Prob. \\
\hline \hline C & 105.2278 & 5.028707 & 20.92543 & 0.0000 \\
Seasons factor 17 & -12.47464 & 1.587229 & -7.859385 & 0.0000 \\
Seasons factor 18 & -6.860673 & 2.714157 & -2.527736 & 0.0120 \\
Apples, is the main activity & 26.24380 & 2.661265 & 9.861402 & 0.0000 \\
\hline \hline
\end{tabular}

\begin{tabular}{lll}
\hline${ }^{3} \mathrm{R}$-squared & 0.462198 & Mean dependent var
\end{tabular}

\footnotetext{
${ }^{2}$ Osmani, M. (2010). The multiple model of regression (pp:49-54). Tirana, Albania, 2010

${ }^{3}$ Osmani, M. (2010). Calculation of the general correlation coefficient (pp. 52-54). Tirana, Albania. (2010)
} 


\begin{tabular}{llll} 
Adjusted R-squared & 0.456747 & S.D. dependent var & 28.80329 \\
S.E. of regression & 21.22967 & Akaike info criterion & 8.961920 \\
Sum squared resid & 133406.9 & Schwarz criterion & 9.011304 \\
Log likelihood & -1340.288 & F-statistic & 84.79600 \\
Durbin-Watson stat & 1.336689 & Prob(F-statistic) & 0.000000 \\
\hline \hline & $=$
\end{tabular}

Seasonality in sales depends by the kind of product (apple or tomato), from unfair competition, by imports and the lack of sales contracting. The model is statistically important for high security with determination coefficient about $46 \%$. From assessment results that seasonality of sale is influenced by S17 and S18 seasonal factors. The seasonality of sale also depends on whether apple is the main activity on farm. When apple is the main activity, seasonality is higher (26.2\%). The size of the farm in this case also results insignificant.

\subsection{The estimation of seasonality dependence of farmer's employment from seasonal factors by econometric modeling.}

\subsubsection{The econometric model for the seasonality dependence of farmer`s employment}

\begin{tabular}{|c|c|c|c|c|}
\hline Variable & Coefficient & Std. Error & t-Statistic & Prob. \\
\hline C & 84.57424 & 8.034421 & 10.52649 & 0.0000 \\
\hline Seasons factor 1 & 5.692025 & 2.276781 & 2.500032 & 0.0130 \\
\hline Seasons factor 13 & -4.910689 & 2.024953 & -2.425089 & 0.0159 \\
\hline Seasons factor 17 & -9.424859 & 2.092790 & -4.503490 & 0.0000 \\
\hline Seasons factor 18 & -7.801944 & 3.324259 & -2.346972 & 0.0196 \\
\hline Apples, is the main activity & -13.71815 & 3.743057 & -3.664957 & 0.0003 \\
\hline Number of employees & 0.299670 & 0.929590 & 0.322368 & 0.7474 \\
\hline The farm size & 0.020598 & 0.321470 & 0.064074 & 0.9490 \\
\hline R-squared & 0.458909 & \multicolumn{2}{|c|}{ Mean dependent var } & 42.76520 \\
\hline Adjusted R-squared & 0.445938 & \multicolumn{2}{|c|}{ S.D. dependent var } & 33.12219 \\
\hline S.E. of regression & 24.65462 & \multicolumn{2}{|c|}{ Akaike info criterion } & 9.274111 \\
\hline Sum squared resid & 177492.3 & \multicolumn{2}{|c|}{ Schwarz criterion } & 9.372878 \\
\hline Log likelihood & -1383.117 & \multicolumn{2}{|c|}{ F-statistic } & 35.37863 \\
\hline Durbin-Watson stat & 1.035909 & \multicolumn{2}{|c|}{ Prob(F-statistic) } & 0.000000 \\
\hline
\end{tabular}

Seasonality of the work-occupation of farmers in farm does not depend by size of farm or by number of employees but depend on the change of temperatures, difficulties in sales, competition from imports, work without sales contracts. At the same time seasonality between apples and tomato is different.

The model is statistically important for high security with determination coefficient about $46 \%$. From the assessment, results that seasonality of employment is influenced by S1, S13, S17 and S18 seasonal factors. The seasonality of employment also depends on whether apple is the main activity on farm. When apple is the main activity, seasonality is lower (13.7\%). The farm size in this

\footnotetext{
${ }^{4}$ Osmani,M.(2013) Methods of econometrics with EViews 3, Lecture, Agricultural University of Tirana, Albania,
} Tirana-Albania 2013. 
case results insignificant.

\subsection{The estimation of seasonality dependence of price from seasonal factors by econometric modeling.}

\subsubsection{The econometric model for the seasonality dependence of price}

\begin{tabular}{|c|c|c|c|c|}
\hline $\begin{array}{l}\text { Dependent Variable: Price } \\
\text { Method: Least Squares } \\
\text { Sample: } 1300 \\
\text { Included observations: } 300\end{array}$ & & & & \\
\hline Variable & Coefficient & Std. Error & $\mathrm{t}$-Statistic & Prob. \\
\hline $\begin{array}{l}\text { C } \\
\text { Seasons factor } 1 \\
\text { Seasons factor } 17 \\
\text { Apples, is the main activity }\end{array}$ & $\begin{array}{l}97.10365 \\
-6.133329 \\
-10.39230 \\
78.66099 \\
\end{array}$ & $\begin{array}{l}6.979643 \\
3.008525 \\
1.948384 \\
4.969430 \\
\end{array}$ & $\begin{array}{l}13.91241 \\
-2.038650 \\
-5.333804 \\
15.82897 \\
\end{array}$ & $\begin{array}{l}0.0000 \\
0.0424 \\
0.0000 \\
0.0000 \\
\end{array}$ \\
\hline $\begin{array}{l}\text { R-squared } \\
\text { Adjusted R-squared } \\
\text { S.E. of regression } \\
\text { Sum squared resid } \\
\text { Log likelihood } \\
\text { Durbin-Watson stat }\end{array}$ & $\begin{array}{l}0.522937 \\
0.518102 \\
37.79439 \\
422811.1 \\
-1513.316 \\
1.177684\end{array}$ & $\begin{array}{l}\text { Mean de } \\
\text { S.D. dep } \\
\text { Akaike i } \\
\text { Schwarz } \\
\text { F-statist } \\
\text { Prob(F-s }\end{array}$ & $\begin{array}{l}\text { dent var } \\
\text { ent var } \\
\text { riterion } \\
\text { erion } \\
\text { tic) }\end{array}$ & $\begin{array}{l}97.18876 \\
54.44398 \\
10.11544 \\
10.16483 \\
108.1545 \\
0.000000\end{array}$ \\
\hline
\end{tabular}

Seasonal variation in price depends on these three factors. Depends on changes of temperatures, competition from imports, and by the kind of product (apple or tomato).

The model is statistically important for high security with coefficient of determination about $52 \%$. From the assessment results that seasonality of price is influenced by $\mathrm{S} 1$, and, S17 seasonal factors. The seasonality of price also depends on whether apple is the main activity on farm. When apple is the main activity, seasonality is higher (about 79\%). The size of the farm in this case also results insignificant.

\section{Conclusions}

From analysis of the seasonal factors that characterize seasonality of farmers' income throughout the year, results that the seasonality dependence of income from seasonal factors by econometric modeling was significant with a high coefficient of determination. But, if the apple would be main activity in farm the impact of seasonal factors on farmer's income would be low. There are also big differences between products apple and tomato. Regarding the seasonality of sales and seasonality of farmers' employement in farm over a year, in both cases it resulted that the econometric model regarding seasonality of sales and seasonality of employment was significant. But in the case of seasonality of sales if apple product would be main activity in farm, then impact of seasonal factors on sale of apple product would be high. While in case of seasonality of employment if apple product would be main activity in the farm, the impact of seasonal factors on farmer's employment on farm during the year would be low. In case of price seasonality it was found that the econometric model regard to seasonality of price was important, if the apple product would be main activity on farm, the impact of seasonal factors on the price of apple product would be high.

\section{References}

Osmani, M. (2010), Calculation of the general correlation coefficient, Vol. II. Tirana, Albania, 2010. Osmani, M. (2004), Coefficient of variation, Tirana, Albania: GEER,2004. 
Osmani, M (2013). Methods of econometrics with Eviews 3 programme.,Lecture, Agricultural University of Tirana, Albania 2013.

Osmani, M.(2010). The multiple model of regression, Vol. II. Tirana, Albania, 2010. 